\title{
The Collapse of American Dinner Rituals in Anne Tyler's Dinner at the Homesick Restaurant
}

\author{
Mary Louisa Cappelli PhD, JD \\ Nevada State College
}

\begin{abstract}
Anne Tyler's Dinner at the Homesick Restaurant (1982) explores the dissolution of the family unit, and the psychological impact on its characters when they can no longer fit into the idealized Dick and Jane heteronormative family paradigm. The dinner place, the empty place that Tyler's father Beck Tull no longer occupies, is the complex focus of Dinner at the Homesick Restaurant. In this essay, I explore how Tyler delves deep into this absence of place and space during the dinnertime ritual as a metaphor for the collapsing family, no father figure dynamic - a world where mother-woman struggles to survive.
\end{abstract}

Keywords- Anne Tyler, Dinner at the Homesick Restaurant, divorce, dinnertime, dysfunctional family, family systems.

\section{INTRODUCTION}

Anne Tyler is one of the most sensitive contemporary Southern authors to provide glimpses into the often times tragic rhythms of American family life. Many of her over sixteen novels explores the gritty details of individuals navigating through the vulnerable landscape of dysfunctional family relationships. Her narrative explorations dive deep into the psychological search for individual realization and a sense of belonging in a fragile family structure. Tyler continues her poignant examination into the personal trauma of abandonment and the collapse of family life in her Faulknerian influenced novel, Dinner at the Homesick Restaurant, (1982). Nominated for the National Book Critics Circle Award, and told from the perspective of a dying Pearl Tull, similar to As I Lay Dying, Dinner a the Homesick Restaurant addresses the changing family dynamics of dinner rituals over the course of thirty years between 1941 and 1970 - a Postwar time of renewed interest in family unity and connectedness. ${ }^{1}$

It was after WWII, that Americans returned to traditional gender roles, reinforcing the heteronormative, two-parent, mother/father structure as a cultural symbol of happiness and security. Considered to be "the matrix of identity," postwar society encouraged and idealized everything family, particularly its triangular patriarchal paradigms, which had the father working and the mother staying at home and tending to the children and domestic affairs (Knapp, 1997, p. 225). This family archetype played an important role in shaping social family constructs as children primers like Dick and Jane of the perfect white mother/father, two children family structure were used in America from 1930 to the 1970 s to teach reading and reinforce family values. Highlighted in the primers and in society, the ritual of the family dinner symbolized heteronormative family togetherness as mother, father, and children ate and shared their daily stories and concerns around the dinner table. Dinnertime was considered "a nurturing place for self-esteem" (Duke, p. 1). It is against this socio-cultural backdrop, that Anne Tyler sets the Tull family, a family torn asunder by the abandonment of their father Beck Tull, and, as a result, the abandonment of the dinnertime ritual. ${ }^{2}$

According to Eudora Welty (1978), "Place is one of the lesser angels that watch over the racing hand of fiction" ( $p$. 117). Tyler's Dinner at the Homesick Restaurant explores the dissolution of the family unit, and the psychological impact on its characters when they can no longer fit into the idealized Dick and Jane American family. The dinner place, the empty space/place that Tyler's father Beck Tull no longer occupies, is the complex focus of Dinner at the Homesick Restaurant. Tyler delves deep into this absence of place and space during the dinnertime ritual as a metaphor for the changing family, no father figure dynamic. For it is the dinnertime ritual, embedded in American psyche that unravels in the Tull Family. Annette Kolodny (2001) refers to Pearl's behavior as "reflexive perception - the sense of finding oneself in a situation, of being dissociated from one's world" (p. 4). Although this may be true, matriarch Pearl Tull's psychological response is to avoid dinnertime altogether so she can disassociate from these feelings.

First articulated by Greek Philosopher Democritus (460370 B.C.), it can be argued that Pearl's avoidance of pain is the motivational stimulus behind her human action at the 
dinner table. Eighteen-century philosopher Bentham provides a prescription for Pearl's psychological behavioral pattern asserting, "Nature has placed mankind under the guidance of two sovereign masters, pain and pleasure. It is for them alone to point out what we ought to do, as well as to determine what we shall do" (p.1). Freud (1890), in his classic Principles of Psychology expands further on this principle, claiming pleasure and pain are the motivational impetus behind all psychodynamic activity (p. 45). Pearl's behavior to keep clear from the negative stimuli of the dinner ritual consequently shapes and molds the personalities of her children, and her own mother-woman being. The children's internalization of Pearl's avoidance behavior provides the psychodynamic dramatic elements as Tyler focuses on the clash between the dominant "ideal" of family and mother-woman and the marginalized Tull family who try to imitate what they have been conditioned to believe is the "objective" reality (McLellan, 2000, p. 67). This clash of ideals provides the narrative framework of Tyler's Dinner at the Homesick Restaurant.

As we shall see, the meaning associated with homesick is complicated and played out in may ways throughout the narrative (Petry, 1996 p. 196). The interpretations are endless. Does homesick mean "sick for home," or a sense of mourning for the loss of the cohesive family unit and the "nostalgic memories" associated with family life? Does it mean "sick of home" itself, the source of pain and suffering? (Petry, 1996, p. 196). Each character has a different psychological interpretation of "homesick." Knapp (1997) points out the paradoxical nature of homesickness: "sick for home or sick of it" (p. 242). Nonetheless, each character must carry his/her "homesickeness" into the revisioning and rewriting of his/her identity after the divorce; each must now make meaning out of the empty spaces hastened by the break-up of the home, the family unit. As such, each member carries the psychological pain of displacement and "homesickness"; the deep longing for all that is associated with home, and family, its joys, its sufferings, and its myriad rituals. In rewriting the empty space, each "character tries to construct a family for him or herself" (Town, 1982 p. 14). Individual family members will rewrite his/her own story forming a gathering of stories based on a familiar Southern family theme-loss and acceptance (Knapp, 1997, p. 228).

\section{ABANDONMENT AND DISPLACEMENT}

We first meet blind, 85-year old Pearl on her deathbed ruminating about the pivotal moments in the unfolding of her motherhood journey. Pearl recalls her story as her memory allows in painful bits and pieces, evoking memories of her earlier 30-year old self when she turned down a college education from Uncle Seward, because she believed "it would be an admission of defeat" (Tyler, 1983, p. 4). Influenced by the social paradigm of the time, Pearl valued the idealized notion of family over a career and individual independence. Perhaps, it is this reason that, when traveling salesman Beck Tull comes and goes, leaving three children in his wake, Pearl cannot accept her new "place" in society as the abandoned wife/mother, especially in a society intolerant of social differences. ${ }^{3}$ Pearl, raised on the social concept of happiness that requires a husband, cannot understand what has happened to her. She tells Beck, "I don't understand you" (Tyler, 1983, p. 10). Not only does Pearl fail to understand her husband, she doesn't understand her new situation, a situation that has left her completely opposite of her ideal self. "This new dynamic creates a sense of social and individual displacement and invalidation" (Makhlouf-Norris \& Norris, 1973, p. 277). Annette Kolodny( 2001) refers to Pearl's behavior as "reflexive perception - the sense of finding oneself in a situation, of being dissociated from one's world" (p.7). As a result, Pearl's response to this perception of her abandonment is to isolate her self further from society and her family by pretending her husband hasn't left. According to Joseph B. Wagner, "She cannot talk to her children about the loss, and they must discover for themselves that their father has left them" (Wagner, 1990, p.72).

Pearl tells her neighbors, Beck is "away on business," so that outsiders can believe the "Tulls are a happy family" (Tyler, 1983, p. 9). She wants to preserve this image for her children also; albeit, at one point when she "had just passed her fiftieth birthday" she was going to tell them, "only she couldn't tell them" (Tyler, 1983, p. 13). Instead, Pearl avoids all mention of Beck's abandonment, closes the curtains to shut out the truth and avoids the source of her pain - the family dinner ritual, an empty place settingwhere Beck's absence is so obvious. According to Elizabeth Evans, the family dinner "stands as a major image, serving as a paradigm for family expectations that come so often to disappointment" (Bail, 1988, p. 133). It is this disappointment Pearl avoids throughout the novel. If she avoids the dinner table and dinner conversation, perhaps the children won't notice and discuss why Beck is not there. Pearl tries to avoid all situations that call for family seating arrangements, picnic gatherings and the like as "they tended to recall only poverty and loneliness" (Tyler, 1983, p. 21). 
After a long day's work at Sweeney Bros. Grocery she comes home to her "second shift" of unpaid labor (Hochschild, 1989). Pearl takes out her frustration by banging noisily in the kitchen, "throwing pots through windowpanes" (Tyler, 1983, p. 50). ${ }^{4}$ Pearl's avoidance of dinnertime is represented in other rushed, unplanned, empty meals of mashed potatoes and undiluted cream of mushroom soup. Exhausted from work and having to take up the "second shift," this time without pay and no financial help from her husband, Pearl struggles as the sole responsible parent and provider of the family. Other times, her exhaustion and sheer frustration from her husband's abandonment has her so upset she brutalizes her children with name calling, "You upstart," and "You wretch, you ugly horror" (Tyler, 1983, p. 71). Her most horrendous wish is that she wished they'd "all die" and end up "dead" in their "beds" (Tyler, 1983, p. 54). Pearl's rage comes at the cusp of the collapse of the American family and the feminization of poverty, which many women face(d) because of divorce. ${ }^{5}$ It is no wonder that she is enraged at her dire financial predicament.

On their first Thanksgiving after the abandonment, there is little gratitude for what has happened to Pearl and her children, hence no turkey, no shared harvest and blessing for this fractured family struggling to maintain some semblance of socially prescribed conventions. This is in contrast to the Norman Rockwell Thanksgiving painting, which appeared on the cover of a 1943 Saturday Evening Post glorifying the ideal American family, the family that "inspired America" (Saturday Evening Post 3/1943). Tyler chips away at this perfect family dinner, showing how Pearl is exhausted and time-staved, juggling work, household duties, childrearing, and dinner planning. Pearl sacrifices herself to maintain some semblance of family, struggling in the shadows of this Normal Rockwell ideal. She feeds her fractured family the best way she can in nutritional fragments. According to Robert W. Croft (1998), "Food is a central metaphor, representing physical and emotional nurturing" (p.11). Pearl's daily hardship to feed her children adequately against the socially accepted paradigm of the family dinner, becomes symbolic of her heroic struggle to be the sacrificing mother-woman.

Pearl's avoidance of the dinner ritual also extends outside her family home, portrayed when the family assembles for the first time at Scarlatti's Restaurant and Pearl breaks it up and heads "towards the door," when she discovers Ezra will not live up to her vision of his being a teacher (Tyler, 1983, p. 96). Ezra, who wants to bring the family back to the table to engage in the ritual of nourishing togetherness, questions why his family cannot "eat a meal from start to finish" (Tyler, 1983, p. 113). On other occasions, Pearl's object avoidance behavior impels her to explode in anger in order to destroy the family ritual before it even commences. She self-reflects and questions her behavior at dinnertime, asking: Why? What is it about dinner that makes her act this way? Elizabeth Evans, in Family Matters: We Make our Own Like, asserts, "Pearl Tull looks at her life, insisting that she had not always been a difficult old woman" (Tyler, 1983, p. 136). Perhaps, Pearl's perception of herself could be true if she had lived in less difficult times, when conventions and social expectations were different. As readers and critics, we can impose our contemporary feminist "what if" perspective: What if she had chosen against the social norm and had gone to college, choosing a path of independence instead of marrying Beck? What if she didn't live in a society that worshipped dogmatic notions of family, ostracizing those who didn't fit in? What if she had accepted the "truth" of Beck's absence in her family? What if she was able to act differently and accept and embrace the changing face of her family, the changing family dinner dynamic? But is it fair to trap Pearl in another paradigm, just because she is a female?

Although Pearl does not evaluate her plight from twentyfirst century feminist codes, she has some degree of selfawareness of her actions at dinner time when she says, "So then, why, I went and made a scene that caused the dinner to be canceled, exactly as If I'd planned it all ahead of time, which of course I hadn't... I know when I'm being unreasonable. Sometimes, I stand outside my body and just watch it all, totally separate" (Tyler, 1983, p. 140). Mother Pearl's behavior is deep, complicated, conflicting; she sincerely wants to know the secret, "often like a child peering over the fence at somebody else's party, she gazes wistfully and wonders what their secret is. They seem so close" (DHR 191). She ponders the secret connectivity of these families, wondering what cohesive unifying element holds them together in a world she perceives as isolating and alienating. "Could it be the fact that they participate in sports? Read books together? Have some common hobby"? (Tyler, 1983, p. 191). She reflects on the mysterious nature of human connection, "these little threads of connection between people," something quite common in Southern Literature (Evans, 1993, p. 10). It is this aching absence that Pearl must reconcile on her journey to understand its impact on her children and family. She wonders if she is to blame for her failed family or if "it's simply fate, and not a matter for blame at all” (Tyler, 1983, p. 191). 
Pearl's self-reflection is itself an act of liberation and movement towards the truth. Contrary to Doris Betts's position (1990), Tyler's characters "do not rebel; they do not kite off for independent lives and careers; they generally appear singularly oblivious to the strong feminist issues of the day" (p. 8). While Pearl certainly doesn't tear down the constraining yellow wallpapered paradigm of postwar society, she does in other ways express rage at her predicament-an abandoned mother-woman forced to financially fight for her family's survival. Albeit, her children suffer from her occasional bouts of frustration, Pearl rises to the challenge, gets a job, and financially supports her family. No, she does not swim far away into the eternal ocean of consciousness like Edna Pontellier abandoning her family responsibilities. Indeed, Pearl is unlike Edna in that she has given up more than the "unessential," more than her "money." Unlike Edna, she has given herself to her children, courageously facing her challenges, as difficult as they are. The claims that Tyler's fiction does not take up "political feminist issues" and does not have a "strong protest against the patriarchy" do not take into consideration the bold dedication of Pearl's time and energy to keep her family financially afloat (Evans, 1993, p. 11). Pearl Tull confronts the family codes of postwar society and the changing face of "mother-woman." Feminist critics do not acknowledge Pearl's boiling rage at a postwar society that sold her a one-way ticket to domestic martyrdom, societal alienation and financial poverty. Feminists with a "capital F" who forged their way to "Fdom" on the backs of the changing face of American postwar "mother-woman" should take note of Pearl's rage, her anger. It is there in all its Fury.

Yes, perhaps this anger is displaced at the dinner ritual and often sadly misdirected at her children, especially Holocaust looking-too-thin-for-her-own-good as a teenager Jenny, the burning rage does nevertheless exist even if it is not recognized in the "average Women Studies Syllabus" (Betts, 1990, p. 3). ${ }^{7}$

\section{The Primal Event}

Pearl's denial of Beck's absence, especially at the traditional custom of dinner, manifests in her anger and rage towards this ritual, Pearl's children bearing the brunt of this anger, each in different ways. Similar to As I Lay Dying, through a series of interconnected narratives, we are front row center to each child's internalization of Pearl's suffering, and his/her perspective, as it impacts individual growth and development. Through the collapse of the family we are privy to the difficulties and shortcomings of parenthood and the impact of "non-nurturing mothers and physical or psychologically absent fathers" on the children (Schneiderman, 1996, p. 20). John Updike (1992) refers to this abandonment as "the primal event," suggesting that the children themselves are victim to a "love that must for survival flee its object, and daily communication that masks silence - that deep resentful silence of those who live together" (p.109).

As the story unfolds, "chapter by chapter gives us Cody's, Jenny's, Ezra's and even Luke's view of the branching consequences of the primal event" (Updike 1992, p. 109). Stuck inside this unspoken cycle of abandonment, Jenny recalls:

which of her children had not felt her stinging slap, with the claw-encased pearl in her engagement ring that could bloody a lip at one flick? She herself, more than once had been slammed against a wall, been called 'serpent,' 'cockroach,' 'hideous little sniveling guttersnipe."” (Tyler, 1983, p. 71)

Jenny internalizes her mother's pain and dreams at night of her mother shrieking at her, dragging her "out of hiding as the Nazis tramped up the stairs" (Tyler, 1983, p. 71). The Holocaust trope used in association with Jenny emphasizes Jenny's emotional and psychological starvation, abuse, and alienation. She's incapable of forging meaningful lasting relationships in her early adulthood, choosing to marry an emotionally disconnected Harley Baines in her senior year, agreeing in an "all right," "no-nonsense communication" (Tyler, 1983, p. 91). It is no surprise Jenny leaves this marriage and returns home. Later, she marries Sam the painter, "one of those graceful compact small types I've never trusted since," someone similar in qualities to her own father, "totally shiftless" and "totally unreliable," who abandons her before Becky is born (Tyler, 1983, p. 198.) For a while, Jenny is a single mother like her own mother, struggling to raise her daughter while attending medical school, as now she struggles to live up to her social ideal of what it means to be a woman, a mother in an ever-changing society. Frustrated at the Helen Gurley Brown influence of balancing motherhood and career, she too lashes out and abuses her own daughter. ${ }^{8}$ This is portrayed when she "slammed Becky's face into her Peter Rabbit dinner plate and gave her a bloody nose"(Tyler, 1983, p. 95) When she yanks out her daughter's hair, "all her childhood" returns to her reinforcing the cycle of abuse and rage at the dinner time ritual (Tyler, 1983, p. 95).

After her divorce to Sam, Jenny marries Joe, a man who has been abandoned by his own wife who fled to Idaho for a "quickie divorce," leaving him with six children (Tyler, 
1983, p. 197). Here, with Joe and the seven children, she finds solace amidst the busy, chaotic rhythms of domestic life. Jenny is strong, suggested by the sign Joe has made her: "Dr. Tull is not a Toy" (Tyler, 1983, p.195). Pushed and pulled in the psychological undertows, she has survived the tumultuous cycle of abandonment and oppressive social expectations. She tells Slevin's teacher that there is no need to blame the past in order to get on in the present saying, "I don't need to blame the adjustment, broken homes, bad parents, that sort of thing. We make our own luck, right? You have to overcome your setbacks. You can't take them too much to heart" (Tyler, 1983, p. 202). Like her mother, Jenny struggled, but ultimately she accepted her past and all its imperfections, developing the habit to see "life on a slant," blending her and Becky into a different kinship structure reflecting the changing face of the American family, redefining and re-visioning what it means to be a family in contemporary society, what it means to be a mother-woman (Tyler, 1983, p. 212).

Brother Ezra's narrative focuses on his need to participate and celebrate the family dinner ritual, one he idealizes as the connecting glue to family solidarity. After Ms. Scarlatti dies, he takes over her restaurant and renames it -"The Homesick Restaurant," a place where families can have family dinner where he would "cook what people felt homesick for" (Tyler, 1983, p. 125). For Ezra, food is nourishment for the body and soul. Different from Cody and Pearl who avoid the dinner ritual, Ezra is mysteriously drawn to it and uses it as a means to nurture and embrace his family. According to Paul Bail (1988), Ezra's attempted family dinners are "the central metaphor," as it is "meant as ritualistic affirmation of family cohesiveness, but, like Sisyphus's boulder that never quite reaches the summit of the mountain" (p.109). Ezra keeps pushing the metaphorical family ritual up the hill towards his ideal in spite of his betrayal by his fiancée Ruth and his brother Cody. Whistle playing, singing "every little soul, must shine," meditative Ezra becomes the caretaker and eyes of his dying mother. ${ }^{9}$ While some critics claim that Ezra mutely absorbs the tragedies of his life, a closer look reveals a sensitive, compassionate feminine quality. Ezra is a spiritual guide, leading Pearl and the family back to itself in its new form. It is more than coincidence that his name is taken from Ezra, the Jewish priestly scribe of 459 BCE who led 5,000 Judean exiles living in Babylon back to their home city of Jerusalem. Ezra Tull is trying to bring his family back home, and as she lay dying, trying to help his mother integrate memories from her past to make sense of the present moment. He offers her the gift of mindful presence spending hours by her bedside, describing old photos and reading from her diary, helping her make sense out of her life, helping her recall that during her life, her existence, she did experience moments of peace, happiness. Pearl finally seems satisfied when Ezra reads a passage, she wrote earlier in her life:

Early this morning ... I went out behind the house to weed. Was kneeling in the dirt by the stable with my pinafore a mess and the perspiration rolling down my back, wiped my face on my sleeve, reached for the trowel and all at once thought, Why, I believe that at just this moment I am absolutely happy.'

His mother stopped rocking and grew very still.

The Bedloe girls' piano scales were floating out her window; he read, 'and a bottle fly was buzzing in the grass, and I saw that I was kneeling on such a beautiful gree little planet. I don't care what else might come about I have had this moment. It belongs to me.'

That was the end of the entry. He fell silent.

Thank you, Ezra,' his mother said. 'There's no need to read anymore.' (Tyler, 1983, p. 287)

Alas, Ezra bridged the gap between past and present for his mother reminding her that she did have moments of happiness, unencumbered by the past or the future. It is this gift of presence Ezra awakens in his mother's memory. Ezra accepts the present conditions and lives in the here and now of time and place and situation, accepting the "what isness" of the here and now. Influenced by Russian Existential Buddhism, Tyler echoes a metaphysical perception of the world, which calls for the serenity of the mind, unaffected by worldly distractions and transcending the ordinary world, leaving the world while in the midst of society. Joseph C. Voelker (1998) acknowledges this worldview, arguing that Ezra can find "comfort in the depths of the eternal present" (p.146). It is this comfort he tries to share with his mother and his family.

A contrasting worldview reveals itself in the most conflicted family member, Cody Tull, who seems to have the same object-aversion to the family dinner ritual as his mother, an object-aversion to the presentness of the ritual. The most wounded child after Beck's departure, and the child Pearl believes is most like her, Cody vies for his mother's love and attention always trying to sabotage his brother Ezra's reputation and place of affection in the family unit. Cody lives his life in competition with Ezra for this love, his antagonistic hostility towards Cody manifesting in a series of cruel childhood pranks against him. The arrow incident early on in his childhood exposes a competition so deep it is reminiscent of the biblical rivalry 
between Abel and Cain, in which elder brother Cain spent his life irritated at having to tend to his younger brother, Abel, and kept asking his parents, "Am I my brother's keeper?"(Genesis 4:9). For Cody, this translates to whether there is enough love to fill the psychic whole of his splintered ego. It is this question, which haunts him throughout his journey, as he confronts his enmity and competes for his mother's love. The arrow, which ends up injuring Pearl, becomes the metaphor for this battle for Pearl's heart and approval. As Pearl lay dying, she recognizes Cody's emotional turmoil wondering if there shouldn't be some "statute of limitations" on his anger and hostility (Tyler, 1983, p. 22). "Was he going to absolve her? He was middle-aged. He had no business holding her responsible any more" (Tyler, 1983, p. 22).

Joseph C Voelker (1998) refers to Cody's emotional life as "entirely made up of 'memories and anticipations,' catalogs of childhood wrongs and a striving for goals that lose their savor as soon as they are within his grasp 'as if anything you can have is something it turns out you don't want"' (p.115). Cody Tull is stuck in a frustrated mother complex, a complex that fuels all his competitive actions, preventing him from being at peace with the present moment, at peace with himself. A successful efficiency engineer, Cody runs from the past into the future, moving his family from town to town, never settling down into the being and now of his presence. Although Paul Bail (1988) affirms that, "Ezra's ease of access to the 'now' is the source of Cody's envy" it is the most signifying source of his psychological discomfort (p.115). His desire to overcome his brother and win his mother's love becomes the motivating factor in his social behavior, as he perceives life as a battlefield that is either won or lost. Paul Bail (1988) asserts that, "Competition is essential to Cody's enjoyment of life as it is a "measurable and commodity like time" (p.110). His quest for this immeasurable affection determines his work choices, as he chooses the same type of business as his father, trying to outdo and compete with this image - all for Peal's affection.

In addition, Cody's conquest of Ruth can be metaphorically described as a conquest for his motherly love. Sadly, this perception of love as a limited commodity clouds Cody's ability to trust the love he so wishes to possess. He compares Ruth's love to that of his mother, saying Ruth has always "loved Ezra better than me" (Tyler, 1983, p. 231). He even thinks Ezra is competing for the love of his son, asking, "Don't you see he's out to steal my son? Don't you see?" (Tyler, 1983, p. 190). Utilizing the italics, Tyler comments on the importance of varying childhood perspectives, which are dependent on the "slant" the angle, given to a circumstance. Whenever Cody recalls his childhood, he prefaces it with "This really happened," implying to the reader, that maybe Cody's childhood narration is not reliable, not taking into consideration the other variables that contributed to the childhood events he has concretized in his mind (Tyler, 1983, p. 227). Always in a psychic battle to achieve more, to prove he is worthy, to assuage his fears that he is not the cause of his father's abandonment, Cody hangs extended in a spatial vacuum. Cody cannot control the past and so he perceives the present as threatening.

Mary J. Elkins (1990) calls this a characteristic of a Faulknerian deterministic world wherein "the past dominates the present, quite often exercising a 'malign influence on the present"' (p.125). Cody carries this behavioral code inside him, reflexively reacting to every situation as another potential rejection and abandonment. Past and future finally collide for Cody when he tells his father what he does for a living and his father responds with pride. He realizes in this moment, "his success had finally filled its purpose," a purpose always outside of time (Tyler, 1983, p. 302). He questions his life's actions and motivations, asking, "Was this all he had been striving for-this one moment of respect flitting across his father's face?" (Tyler, 1983, p. 302). Cody's childhood perceptions are further called into question, when he complains about his mother and Ezra offers a different perspective. "Think of the other side," Ezra told him, awakening in him another way to view the world, another "slant" (Tyler, 1983, p. 306).

\section{Family Staple: Forgiveness}

Ironically, at the end of the novel, it is Cody who runs after Beck after his final act of abandonment when the baby is choking at Pearl's memorial dinner. In this interaction, we realize that Cody had internalized his father's mores and perception of time of always having "a purpose" like "you are heading someplace purposeful" so that "none of the lowlife will mess with you" (Tyler, 1983, p. 309). Beck confesses his difficulty in being comfortable in the present, telling Cody how whenever a woman got too close to him, he would move on. "Oh, it's closeness that does you in," he says again showing the significance of space and time (Tyler, 1983, p. 312). With the knowledge from the past, Cody is finally able to awaken to the present as he sees "his family rounding the corner, opening like a fan" (Tyler, 1983 , p. 314). He is "surprised and touched," as he can finally see the vibrant life around him and is transformed 
into the present, as "seagulls drifted through a sky so clear and blue" that it brought back happy memories of his childhood, as if the painful childhood memory had lifted so he could see that "little brown airplane, almost motionless, droning through the sunshine like a bumblebee" (Tyler, 1983, p. 314).

Pearl's funeral finally brings everyone back to the dinner table for one last dysfunctional meal. A sense of forgiveness and acceptance awakens among them, especially Beck and Cody, as "forgiveness is possible only after understanding" (Spector, 1997, p.323). The echoes of Ezra's vision of merging the past and present become more poignant: "All we have is each other...We've got to stick together, nobody else has the same pat that we have" (Tyler, 1983, p. 338).

In the end, the past, present, and future finally transcend space in what Mary J. Elkins (1990) describes as a "devaluation of chronology," as the family comes to terms with the past and place and settles into the gathering moment of presence (p. 78). It is as if Pearl planned it this way all along with her funeral invitation to Beck. From this perspective, this slant, the memory - the pain becomes the pearl.

\section{REFERENCES}

[1] Bail, P. (1999)A Critical Companion. Westport Connecticut: Greenwood Press

[2] Bentham, J. (1970).An Introduction to the Principles of Morals and Legislation. Ed. J.H. Burns and H.L.A. Hart, London: The Athlone Press.

[3] Betts, D. (1990). “Tyler's Marriage of Opposites.” The Fiction of Anne Tyler. Edited by Ralph Stephens. Oxford: University Press of Mississippi.

[4] Chopin, K.(1899).The Awakening. Chicago, New York: Herbert S. Stone \& Co.

[5] Croft, R. (1998).W. Anne Tyler Companion. Westport: Greenwood Press.

[6] Duke, M.(2008).“Today I...”:Ritual and Spontaneous Narratives During Family Dinner.Atlanta: The Emory Center for Myth and Ritual in American Life, Working Paper No. 31.

[7] Elkins, J. M.(1990)."Dinner at the Homesick Restaurant: Anne Tyler and the Faulkner Connection." The Fiction of Anne Tyler. Edited by Ralph Stephens. Oxford: University Press of Mississippi.

[8] Evans, E. (1992).Anne Tyler. New York: Twayne Publishers.

[9] McLellan, D. (2000).Karl Marx Selected Writings $2^{\text {nd }}$ Edition. USA: Oxford University Press.
[10]Freud, S. (1922). Beyond the Pleasure Principle.London: The International PsychoAnalytical Press.

[11]Kelly, G. A. (1995).The Psychology of Personal Constructs. Vol. 2. New York: W. W. Norton.

[12] Kolodny, A. (2001)."Dancing Through the Minefield: Some Observations on the Theory, Practice, and Politics of Feminist Literary Criticism." The Norton Anthology of Theory and Criticism. Vincent B. Leitch, ed. New York: W.W. Norton and Company.

[13] Knapp, J. V. (1997)."Family systems psychotherapy, literary character, and literature: An Introduction." Style; Summer 1997; 31, 2; Research Library

[14] Makhlouf-Norris, F. \& Norris, H. (1973)."The Obsessive Compulsive Syndrome as a Neurotic Device for the Reduction of Self-uncertainty." British Journal of Psychiatry.www.best-norman-rockwellart.com/norman-rockwell-saturday-evening-post article-1943-03-06-freedom-from-want.html

[15] Petry, H, A.(1992).Critical Essays on Anne Tyler.NY: G.K. Hall \& Co.

[16] Schneiderman, L. (1996). "Anne Tyler: The American Family Fights for its Half-Life.”American Journal of Psychoanalysis March 1996: 65-81

[17] Spector, J. A. (1997). "Ann Tyler's Dinner at the Homesick Restaurant: a critical feast." Style, 31, 2.

[18] Town, C. J. (1992). "Rewriting the Family During Dinner at the Homesick Restaurant." Southern Quarterly 31:1 (1992) 14-23

[19] Tyler, A. (1983).Dinner at the Homesick Restaurant.Knopf, New York City: Knopf.Updike, John"Dinner at the Homesick Restaurant: From "On Such a Beautiful Green Little Planet."

[20] Voelker, J.C.(1998). Art and the Accidental in Anne Tyler. Columba: University of Missouri Press.

[21] Wagner, J. B. (1990). "Beck Tull: 'The Absent presence' in Dinner at the Homesick Restaurant." The Fiction of Anne Tyler. Edited by Ralph Stephens. Oxford: University Press of Mississippi, 1990. Print.

[22] Welty, E. (1978). "Place in Fiction," in The Eye of the Story: Selected Essays and Reviews, New York: Random House.

\footnotetext{
${ }^{1}$ According to Mary J. Elkins (1990), "Tyler may be intending evocation," as in this novel, "a mother's death brings together her family to participate in a ritual act: funeral journey in one, a funeral dinner in the other" ( $p$. 119). Whether this is an act of revenge against her family is debatable, but not a topic explored herein.
} 
${ }^{2}$ Tyler's formative years were influenced by the changing socio-cultural dynamic of the time reflected in her own mother's choice of bedtime stories, Virginia Lee Burton's Little House, "which could be seen as the story of agrarian ideal destroyed by modernism and commercialism and of an attempt to restore the lost way of life" (Bail, 1998, p. 15).

${ }^{3}$ Beck up and left "one Sunday night in 1944," corresponding to the time frame of the Holocaust perhaps, suggesting a similar annihilation of the Tull family (Tyler, 1983, p.7).

${ }^{4}$ I refer to the myriad discussions of the feminization of poverty at this juncture in the collapse of the American family.

${ }^{5}$ This is a reference to Kate Chopin's The Awakening.

${ }^{6}$ Mother-women "idolized their children, worshipped their husband, and esteemed it a holy privilege to efface themselves as individuals and grow wings as ministering angels (Chopin, 1899, p. 29).

${ }^{7}$ At this point, if the reader has not picked up on this yet, I am sympathetic to Pearl's rage as a divorced educated woman of three young children in the 1990s who was faced with similar circumstances. How do I combat an entrenched patriarchy willing to sell out child support-a mere family pittance for financial gain?

${ }^{8}$ In 1960s, Helen Gurley Brown claimed that women could have it all, "love, sex, and money."

${ }^{9}$ From a Faulknerian perspective, Ezra can be compared to Cash in "their uncomplaining acceptance of whatever must be" (Elkins, 1990, p. 120). 